\title{
Coastal brachyuran decapods: settlement and recruitment under contrasting coastal geometry conditions
}

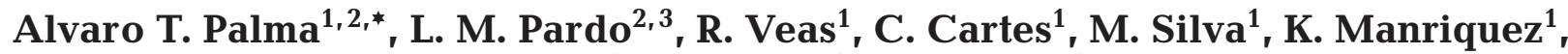 \\ A. Diaz ${ }^{1}$, C. Muñoz ${ }^{1}$, F. P. Ojeda ${ }^{1,2}$ \\ ${ }^{1}$ Departamento de Ecología, and ${ }^{2}$ Center for Advanced Studies in Ecology and Biodiversity, \\ Pontificia Universidad Católica de Chile, Alameda 340 Casilla 114-D, Santiago, Chile \\ ${ }^{3}$ Laboratorio Costero Calfuco, Instituto de Biología Marina ‘Jürgen Winter', Universidad Austral de Chile, \\ Casilla 567, Valdivia, Chile
}

\begin{abstract}
The importance of coastal morphology, and its influence on the magnitude of larval delivery and subsequent recruitment patterns of brachyuran decapods, was investigated at a broad range of spatial and temporal scales along the central coast of Chile. Larvae were quantified through plankton net towing as well as by using artificial settlement collectors deployed at different depths, while the abundance of benthic stages was quantified via in situ SCUBA airlifting and visual surveys. The abundance of young-of-the-year (YOY) and of individuals older than 1 yr (>1 yr) was compared between sites with contrasting conditions of coastal exposure at peninsulas several hundred kilometers apart. Additionally, we pursued a temporally more detailed surveying program, which included more species, at the southernmost peninsula. From our results we conclude that: (1) in general, the abundance of Paraxanthus barbiger, the most abundant species throughout, was greater at all locations in 2003 compared with 2004 and it was also greater (particularly >1 yr individuals) at protected sites; (2) for most of the species, the abundance of megalopae and YOY was highly seasonal, with peaks during the austral spring and summer months; and (3) for at least 2 of the 4 species considered in the southernmost peninsula, the abundance of YOY and $>1 \mathrm{yr}$ individuals exhibited higher abundance at the protected site. In spite of our efforts, we failed to find significant correlation between local abundance of settlers on artificial collectors and YOY individuals that settled in nursery habitats directly below. Post-settlement mortality, operating very soon after settlement, is a likely explanation for this finding. Our study highlights the importance of considering factors such as coastal morphology together with the occurrence of post-settlement processes when studying coastal organisms with complex life cycles.
\end{abstract}

KEY WORDS: Recruitment · Settlement · Physical factors $\cdot$ Larval delivery $\cdot$ Brachyuran decapods · Coastal morphology $\cdot$ Larval supply

Resale or republication not permitted without written consent of the publisher

\section{INTRODUCTION}

Coastal zones around the world represent the habitat for many benthic marine species with a dispersive larval phase. The study of their populations is particularly difficult because of the generally poor information regarding basic aspects of the distribution, abundance and fate of their larvae. A better understanding of factors affecting the demography of these organisms is not just of scientific relevance, but is also important when considering that many represent commercially exploited species. The lack of basic biological and ecological information may result in poor management decisions and consequent risks to the conservation of the resources (Tuck \& Possingham 2000). The importance of physical factors affecting the variability of larval supply has also been emphasized (e.g. Botsford 2001); however, there is still need for research, mainly focused on the identification and quantification of the transport mechanisms operating near the time of set- 
tlement (Pineda 2000). Of interest are linkages between patchiness in larval supply and local population structure of the benthic population (e.g. McCulloch \& Shanks 2003, Shanks et al. 2003, Menge et al. 2004).

From a large-scale perspective (e.g. thousands of kilometers) and regarding the supply of larvae, there is evidence to suggest the existence of different processes acting at those scales. Research conducted along the North American west coast described how intertidal sessile invertebrates exhibit patterns of abundance, related to the different processes operating at scales of hundreds of kilometers between Oregon and California (Roughgarden et al. 1988). A greater importance of density-dependent-type processes (i.e. predation, competition) was detected in zones where oceanographic conditions promote a greater incidence of larvae near the coast. In contrast, density-independent factors (i.e. those affecting the supply of larvae) explained the demographic patterns in environments where larvae were comparatively rare (Shkedy \& Roughgarden 1997, Connolly \& Roughgarden 1998, 1999 and references therein). Such studies describe the patterns of community structure of adults in the benthos and of larvae in the water column at regional scales (Connolly \& Roughgarden 1998). However, those studies lack information about the patterns and processes that could be affected by factors operating at much smaller (meters to kilometers) scales. Although relevant, these small-scale considerations are not new and several studies, particularly in estuarine systems, have investigated the consequences of local circulation upon the distribution of various organisms with planktonic larvae (e.g. Wood \& Hargis 1971, Cronin \& Forward 1982, Sulkin \& van Heukelem 1982, Boicourt 1988). More recently, the necessity of testing hypotheses related to the demography of benthic species undergoing a larval phase, at smaller spatial scales, has been recognized and considered in other studies (i.e. Jenkins et al. 1997, Archambault \& Bourget 1999, Palma et al. 1999, McCulloch \& Shanks 2003).

Despite these efforts, it is still inconclusive how physical (pre-settlement) and biotic (post-settlement) type processes interact in order to provide a more unified perspective that would explain the local demography of species that undergo a planktonic dispersive phase (e.g. Heck et al. 2001, Armsworth 2002, Delany et al. 2003). Moreover, the necessity of integrating physical and biological processes through a wide range of spatial and temporal scales should not be underestimated (Hughes et al. 1999, Sale 1999, Botsford 2001). There is ample evidence showing how local processes (e.g. competition, predation), mostly quantified after the larvae have settled, can explain the patterns of distribution and abundance (e.g. Wahle \& Steneck 1992, Carr \& Hixon 1995, Eggleston \& Arm- strong 1995, Forrester 1995, Palma et al. 1999, Palma \& Steneck 2001, Doherty et al. 2004). On the other hand, for the majority of marine benthic invertebrates that are slow moving or even sessile as adults, the larval phase is regarded as the only effective stage for dispersion. The supply of larvae then becomes an important factor affecting benthic community structure at some coastal sites (e.g. Gaines \& Roughgarden 1985, Roughgarden et al. 1988). Several studies have shown a positive relationship between larval supply and settlement (e.g. Gaines \& Roughgarden 1985, Minchinton \& Scheibling 1991), while in others, although present, this relationship is less obvious (Miron et al. 1995). Thus, one naturally poses the question: At what spatial scale does each type of process (larval supply vs. benthic interactions) become more important, or at least responsible for explaining the greatest amount of the observed variance?

Central Chile's coast represents an ideal place to pursue an answer to such a question. From a large-scale perspective (as from outer space), the Chilean coast looks like a straight line, and one would expect that oceanographic large-scale forces would equally affect the advection of larvae towards coastal settling grounds. Upon closer look, however, the coastline exhibits features (i.e. bays, head lands) that could be assumed to represent obstacles for the incoming larvae.

Recent studies have proposed that coastline configuration can have an important effect on ecological patterns, particularly by affecting the abundance and diversity of benthic organisms (Archambault et al. 1998, Archambault \& Bourget 1999), observing greater abundance in coastal zones protected from highvelocity currents. The coastline configuration can also modify the local hydrodynamics at greater spatial scales (Okubo 1973, Signell \& Geyer 1991) by creating gyres or fronts that can alter the dispersion of particles, including zooplankton (Lobel \& Robinson 1986, Wolanski \& Hamner 1988, Signell \& Geyer 1991). These conditions could favor the entrapment and retention of larvae, thereby enhancing settlement (Murdoch 1989, Thiébaut et al. 1994, Graham \& Largier 1997, Wahle \& Incze 1997). While the local abundance of larvae increases, so does their retention time, thus enhancing the conditions for successful settlement.

Brachyuran decapod crustaceans represent a common group of invertebrates along the coast of Chile, with benthic (juvenile and adults) as well as planktonic stages (zoeas and megalopae) that are easily quantified. Larval stages of brachyuran decapods spend a variable period of time in the plankton (on the order of weeks) and are generally capable of long-distance dispersal; mortality is typically high during this period (Elner \& Campbell 1991, McConaugha 1992). For the most part, brachyuran larvae are neustonic (Pineda 
1999, Shanks et al. 2000), which makes their shoreward advection subject to the influence, among other factors, of wind (McConaugha 1992, Govoni \& Pietrafesa 1994, Garland et al. 2002), internal wave fronts (Pineda 1999), or fronts associated with upwelling and relaxation events (Shanks et al. 2000).

Several species of brachyuran decapods are found along the coast of central Chile (Lancellotti \& Vasquez 2000) that play an important ecological role in the intertidal and subtidal communities. In these systems, brachyuran crabs are important consumers (scavengers and predators) and are also part of the diet of other predators, mainly fishes (Castilla 1981, Fariña \& Ojeda 1993, Ojeda \& Fariña 1996, Palma \& Ojeda 2002). In spite of their diversity and abundance, there is still a lack of basic information on their abundance, distribution and the processes affecting the dynamics of their populations. We have chosen several species of brachyuran decapods (crabs) as model animals for this study; the reasons for these choices are multiple: (1) they are abundant and easily identifiable organisms, in both benthic and planktonic phases; (2) they have a life cycle with fairly discrete (annual) settlement pulses that can be well quantified; and (3) some of the selected species are commercially harvested, permitting a comparison of patterns between fished and non-fished species.

In the present study we considered several species of crabs and quantified the supply of competent larvae, the abundance of individuals after settlement, as well as older segments of local populations. The main factor taken into account for the design of these surveys was that each location had sites with contrasting conditions of coastal exposure. Hence, the general working hypothesis considered here states that irregularities along the coast line (i.e. exposed vs. protected sides of a peninsula) represent scenarios that will generate differences in the amount of larvae that will arrive, and possibly settle, this being greater at protected sites. Our approach also seeks to understand how (and at what scales) the 2 types of general processes (physical that affect the advection of larvae vs. biological interactions occurring soon after settlement) affect their local patterns of abundance after settlement.
In particular, this research considers 2 specific objectives: (1) to compare the patterns of abundance of these species between sites with contrasting exposure and (2) to investigate whether local abundance of presettled competent larvae and newly settled individuals of species of crabs explains the local abundance of subsequent recruits of these species.

\section{MATERIALS AND METHODS}

Site selection and surveying techniques. A series of locations along the coast of Chile, ranging over $1000 \mathrm{~km}$, were chosen for this study (Fig. 1). Each loca-

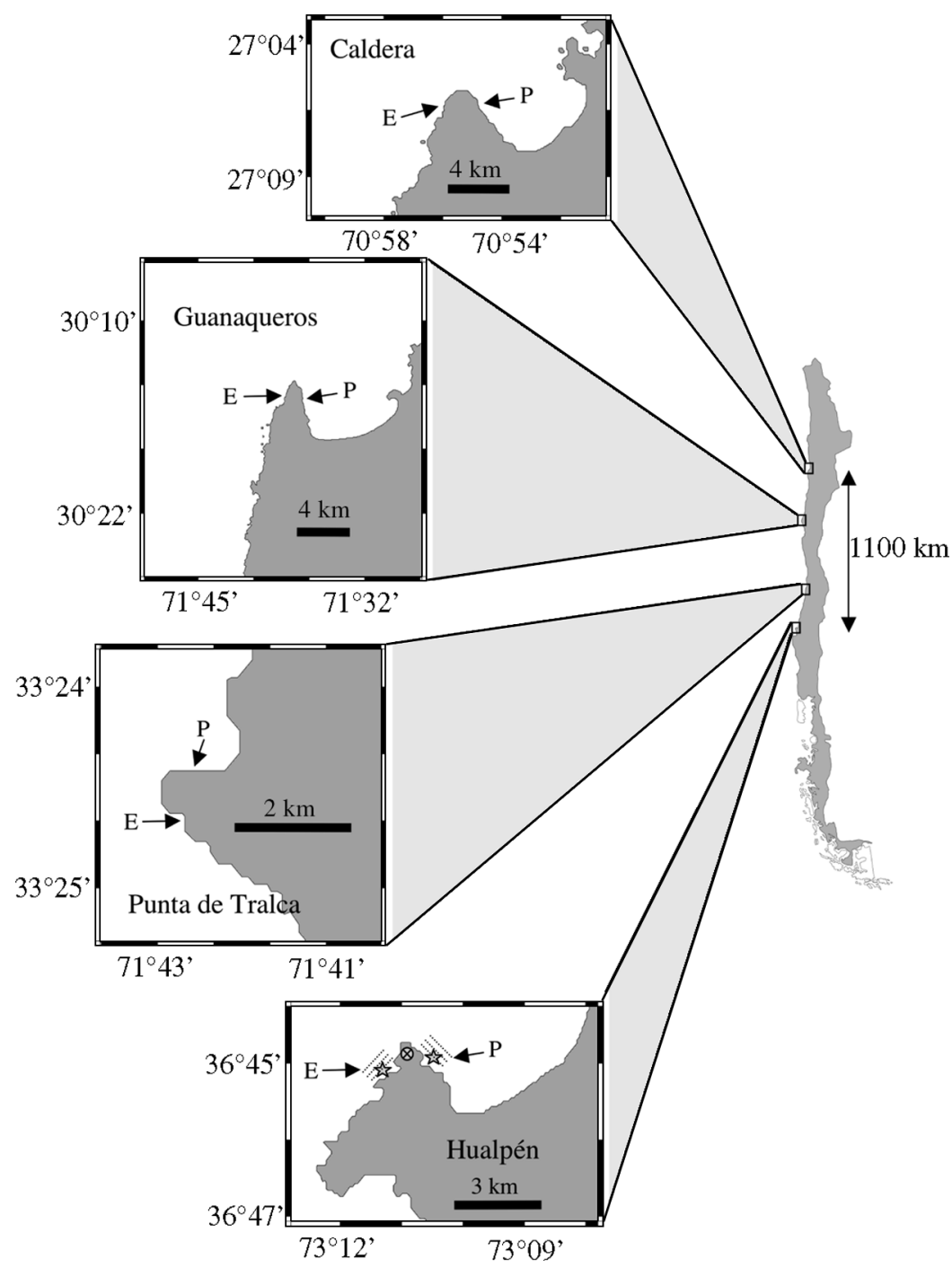

Fig. 1. Study locations along the north-central coast of Chile with exposed (E) and protected (P) study sites indicated. At the southernmost location (Hualpén)

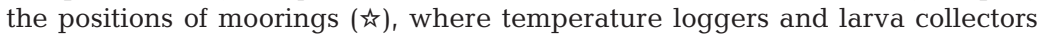
were attached, and meteorological station $(\otimes)$ are shown. Dashed lines along each side of the peninsula represent the approximate positions of transects followed for plankton tows 
tion, characterized by the presence of a peninsula, included 2 sites, one exposed and the other considered protected since it was located within the bay facing to the north (Fig. 1). Given the importance of the coastline geometry in the context of this study, the position of each site within each location was roughly equidistant to the tip of each peninsula. The presence of cobblestones along the bottom was a requisite for site selection, because of their importance as a suitable habitat for large decapods in general (Wahle \& Steneck 1991, Palma et al. 1998) and for these species in particular (Palma et al. 2003). Two different surveying schemes were implemented during our study that also differed in the frequency of their occurrence. A lowfrequency sampling consisted of surveys at the 4 locations (each with 2 sites) visited twice, one in September of 2003 and the other in October of 2004. Although several species of brachyuran decapods were found at these 4 locations, we chose to compare only the abundance of Paraxanthus barbiger among sites and peninsulas, since it was the only species abundant enough, suitable for statistical analyses and with all size ranges consistently present throughout (Table 1). Higher frequency sampling was implemented monthly from June 2002 until June 2004 on 1 of the peninsulas (Hualpén, Fig. 1) and included several other crab species.

The distribution and abundance of newly settled and adult phases of the local populations were quantified through substrate-specific (i.e. cobblestone on a shell hash matrix) surveys at depths between 10 and $12 \mathrm{~m}$ below mean low water (BMLW) at each site by haphazardly placing square frames within the area. During each survey, at least 10 frames of $0.25 \mathrm{~m}^{2}$ were utilized, and all loose material (including organisms) was suctioned with an airlift device (methodology after Wahle \& Steneck 1991). Samples were collected inside a catch bag ( $1 \mathrm{~mm}$ mesh size) and transported alive to the laboratory for sorting. All crabs were identified to species level and measured to the nearest $0.1 \mathrm{~mm}$. Since this collecting technique is specifically designed for catching small and newly settled individuals, additional visual censuses were performed at the same sites and depths in order to quantify the older (larger) individuals of these crab species. To accomplish this, during each monthly survey divers haphazardly placed on a specific substrate (cobbles-boulders on shell hash) a minimum of ten $1 \mathrm{~m}^{2}$ square frames along the bottom; the divers counted and measured in situ all crabs present and then released them. Individuals of all species were conservatively considered young-of-the-year (hereafter YOY) when carapace width (CW) was $\leq 5 \mathrm{~mm}$; this decision was based on size-frequency analyses in which strong modes, ranging from 3 to $7 \mathrm{~mm}$, were evident for all species considered in this study. Following the same considerations, individuals with $\mathrm{CW}>10 \mathrm{~mm}$ were classified as older than $1 \mathrm{yr}$ (hereafter $>1 \mathrm{yr}$ ).

Artificial settlement substrata. A more detailed quantification of the abundance of newly settled individuals of

Table 1. Presence/absence of brachyuran species at the 4 study localities and 8 sites (Exp.: exposed; Prot.: protected) along the central and northern Chilean coast. Data correspond to those obtained from visual and airlift suction sampling censuses during springtime (2003 and 2004)

\begin{tabular}{|c|c|c|c|c|c|c|c|c|}
\hline \multirow[t]{2}{*}{ Species } & \multicolumn{2}{|c|}{ Caldera } & \multicolumn{2}{|c|}{ Guanaqueros } & \multicolumn{2}{|c|}{ Pta. de Tralca } & \multicolumn{2}{|c|}{ Hualpén } \\
\hline & Exp. & Prot. & Exp. & Prot. & Exp. & Prot. & Exp. & Prot. \\
\hline \multicolumn{9}{|l|}{ Cancridae } \\
\hline Cancer coronatus Molina, 1782 & & & & & & $\mathrm{X}$ & & $\mathrm{X}$ \\
\hline Cancer edwardsi Bell, 1835 & & & & & $\mathrm{X}$ & & & $\mathrm{X}$ \\
\hline Cancer porteri (Rathbun, 1930) & & & & & & & & $\mathrm{X}$ \\
\hline Cancer setosus Molina, 1782 & $\mathrm{X}$ & $\mathrm{X}$ & $\mathrm{X}$ & $\mathrm{X}$ & $\mathrm{X}$ & $\mathrm{X}$ & $\mathrm{X}$ & $\mathrm{X}$ \\
\hline \multicolumn{9}{|l|}{ Hymenosomatidae } \\
\hline Halicarcinus planatus (Fabricius, 1775) & & $\mathrm{X}$ & & & $\mathrm{X}$ & $\mathrm{X}$ & $\mathrm{X}$ & \\
\hline \multicolumn{9}{|l|}{ Majidae } \\
\hline Pisoides edwardsi Bell, 1835 & $\mathrm{X}$ & $\mathrm{X}$ & $\mathrm{X}$ & & $\mathrm{X}$ & $\mathrm{X}$ & $\mathrm{X}$ & $\mathrm{X}$ \\
\hline Taliepus spp. ${ }^{\mathrm{a}}$ & $\mathrm{X}$ & & $\mathrm{X}$ & $\mathrm{X}$ & $\mathrm{X}$ & $\mathrm{X}$ & $\mathrm{X}$ & $\mathrm{X}$ \\
\hline \multicolumn{9}{|l|}{ Pinnoteridae } \\
\hline Pinnixa spp. & & $\mathrm{X}$ & & & & & & \\
\hline \multicolumn{9}{|l|}{ Xhantidae } \\
\hline Gaudichaudia gaudichaudi (H. Milne Edwards, 1834) & $\mathrm{X}$ & $\mathrm{X}$ & $\mathrm{X}$ & $\mathrm{X}$ & $\mathrm{X}$ & $\mathrm{X}$ & $\mathrm{X}$ & $\mathrm{X}$ \\
\hline Homalaspis plana (H. Milne Edwards, 1834) & & $\mathrm{X}$ & & & $\mathrm{X}$ & $\mathrm{X}$ & $\mathrm{X}$ & $\mathrm{X}$ \\
\hline Paraxanthus barbiger (Poepping, 1836) & $\mathrm{X}$ & $\mathrm{X}$ & $\mathrm{X}$ & $\mathrm{X}$ & $\mathrm{X}$ & $\mathrm{X}$ & $\mathrm{X}$ & $\mathrm{X}$ \\
\hline Pilumnoides perlatus (Poepping, 1836) & & $\mathrm{X}$ & $\mathrm{X}$ & & $\mathrm{X}$ & $\mathrm{X}$ & $\mathrm{X}$ & $\mathrm{X}$ \\
\hline Total species (per site) & 5 & 8 & 6 & 4 & 9 & 9 & 8 & 10 \\
\hline Total species (per locality) & & & & & & & & 1 \\
\hline
\end{tabular}


the 3 most abundant species that occurred at the Hualpén location (Cancer setosus, Paraxanthus barbiger and Pilumnoides perlatus) was performed at each study site during part of the 2003 to 2004 settlement season using experimental bottom collectors. At each site, 3 identical units were deployed that corresponded to $0.5 \mathrm{~m}^{2}$ square $(71 \times 71 \times 20 \mathrm{~cm})$ wire baskets lined with nylon screen (1 mm mesh). Each tray was filled with a $1 \mathrm{~cm}$ deep layer of clean shell hash and cobbles previously obtained from each site. Collectors were deployed on December 29, 2003, and were surveyed using the abovedescribed suction sampling technique on 5 occasions, between January 8 and January 21. The longest period between surveys was $5 \mathrm{~d}$. After each survey new and clean shell hash was added to each tray, and cobbles were placed back forming a compact layer. Samples were analyzed in the laboratory, and the abundance of newly settled individuals ( $\leq 5 \mathrm{~mm} \mathrm{CW}$ ), expressed as number of YOY $\mathrm{m}^{-2} \mathrm{~d}^{-1}$, was obtained by multiplying the numbers by 2 and dividing by the number of days that the collectors were exposed since the last survey.

An early estimation of the abundance of competent brachyuran larvae (megalopae) of the 3 most abundant species in Hualpén (Cancer setosus, Paraxanthus barbiger and Pilumnoides perlatus) was obtained on a monthly basis from September 2002 until July 2004. At each site, 2 groups of 4 circular-shaped artificial plastic mesh collectors (scrubbing pads) of $10 \mathrm{~cm}$ diameter were attached to a mooring line, approximately $10 \mathrm{~cm}$ apart, one near the surface and the other at $10 \mathrm{~m}$ BMLW. During these 23 mo, collectors were retrieved and replaced with new ones every few days (between 2 and $15 \mathrm{~d}$, intervals largely imposed by weather conditions) by divers who introduced each collector inside a plastic bag and sealed it underwater. This procedure was repeated 62 and 59 times at the exposed and protected site, respectively. The collectors were quickly transported to the laboratory inside a cooler in order to obtain live individuals. This procedure enabled us to accurately identify most species, and to identify unknown megalopae by allowing them to molt into juvenile stages under laboratory conditions. The abundance of newly settled megalopae at each depth was expressed as number of settlers collector ${ }^{-1} \mathrm{~d}^{-1}$, calculated by averaging the number of individuals that settled on each of 4 collectors and dividing them by the number of days that the collectors were exposed since the last survey. The abundance data from these collectors are presented as monthly averages. A gap in the time series occurred in March of 2003 and was due to the loss of the mooring lines.

Plankton sampling. Megalopae of the main 3 species present in the water column were also quantified using 2 types of nets, a floating epineustonic net designed to collect the surface-dwelling larvae (rectangular mouth of $0.8 \times 0.4 \mathrm{~m}, 250 \mu \mathrm{m}$ mesh size) and a sub-surface net (circular mouth of $60 \mathrm{~cm}$ diameter, $250 \mu \mathrm{m}$ mesh size) which was towed at approximately $5 \mathrm{~m}$ depth (see details of the same methodology in Poulin et al. 2002). The volume of water filtered was obtained from flowmeters attached to the mouth of each net. At each site (exposed and protected), once a month and using 2 similar small boats, from September of 2002 to July 2004 (except December 2002, February 2003 and May 2004 when tows were not performed), the 2 nets were simultaneously towed along 3 previously georeferenced $800 \mathrm{~m}$ long transects (Fig. 1). Transects were oriented roughly parallel to the coastline at each site and approximately 200, 400 and $600 \mathrm{~m}$ from shore, respectively. Plankton samples were preserved in a $5 \%$ buffered formalin seawater solution, and larvae were then sorted, identified and counted in the laboratory under a dissecting scope. Each monthly value corresponded to the sum of all megalopae captured by the 2 nets along the 3 transects. Larval abundance was standardized to the number of individuals per $100 \mathrm{~m}^{3}$.

Hydrographic variables. Physical data from Hualpén consisted of records of wind velocity and direction and water column temperature. Wind data were continuously registered at $10 \mathrm{~min}$ sampling intervals throughout the study period by a meteorological station (Licor-1400) located at the tip of Hualpén peninsula (Fig. 1). Gaps in the time series were due to technical problems with the instrument. Simultaneous records of surface and bottom water column temperature, registered every $10 \mathrm{~min}$, were obtained from loggers (Stow Away Tidbits, Onset Computers, with $\pm 0.3^{\circ} \mathrm{C}$ precision) attached to the moorings located at each side of the peninsula (Fig. 1). Moorings were positioned at points above the isobath of $20 \mathrm{~m}$. Loggers were attached at 3 and $20 \mathrm{~m}$ below the surface.

Data analyses. We performed nested ANOVAs to compare differences in number of individuals at both spatial and temporal scales. To compare the abundance, between sites of contrasting exposure and among widely separated locations, based on the effect of time (years or months of survey), YOY and $>1 \mathrm{yr}$ individuals were tested separately. In this analysis, year was used as the random factor (since we did not have any preconceived notion of what to expect), while exposure and locality represented fixed factors based on our original working hypothesis. Only Paraxanthus barbiger was used, since it was the most persistent and abundant species throughout our spatial and temporal coverage. Nested ANOVAs were also used to test the effect of year and month, as well as of degree of exposure on the density of settlement and recruitment for 4 of the most abundance species collected in Hualpén between 2002 and 2004. In this analysis the factor month was nested within 
year, and YOY and $>1$ yr individuals were tested separately. Since the design of this analysis was not orthogonal (i.e. missing data for some months), we used Type IV sum of squares in order to obtain the estimated probabilities (Sokal \& Rohlf 1995). For the sake of clarity, these results are summarized in a table (see Table 3).

To test whether the abundance of competent larvae (megalopae) settled into collectors was reflected in the subsequent abundance of newly settled individuals (YOY) and to visualize the time delay between the signal from the plankton and the one detected in the benthos, we determined the Spearman correlation coefficients $\left(r_{s}\right)$ between larvae present in the collectors at each depth, as well as their added values, and individuals found through bottom suction samples (Sokal \& Rohlf 1995). These correlations were performed for each of 3 species with time lags ranging from 0 to 4 mo. To maintain an equivalent number of sample units for each correlation, the last 4 mo were eliminated from the analysis for each species.

The difference between the abundance of competent larvae (megalopae) that settled into collectors at 2 different depths and of newly settled individuals inside bottom collectors at the 2 sites of Hualpén was tested through a 2 (exposure and depth) and 1 (exposure) factor ANOVA, respectively. In each case, and due to the relatively small number of replicates, data were pooled for the whole period. In both cases the data were square-root transformed.

Throughout the study the assumptions of normality, homogeneity of variance and independence of observations were tested, and the appropriate transformations were performed when necessary (Sokal \& Rohlf 1995). Higher level interactions were analyzed with a Student-Newman-Keul's test.

Table 2. Nested ANOVAs for differences in mean densities of young-of-the-year (YOY) and Paraxanthus barbiger older than $1 \mathrm{yr}(>1 \mathrm{yr})$ between years (2003 and 2004) in 4 locations and sites of contrasting exposure. Bold: significant p-values

\begin{tabular}{|lcrrrr|}
\hline Source of variation & Effect & df & MS & $F$ & $\mathrm{p}$ \\
\hline YOY & & & & & \\
Year & Random & 1 & 28.86 & 18.76 & $\mathbf{0 . 0 2 3}$ \\
Location & Fixed & 3 & 22.75 & 3.67 & 0.121 \\
Exposure (Location) & Fixed & 4 & 6.19 & 2.2 & 0.231 \\
Year $\times$ Location & Random & 3 & 1.54 & 0.55 & 0.676 \\
Year $\times$ Exposure (Location) & Random & 4 & 2.81 & 2.41 & 0.053 \\
Error & & 114 & 1.16 & & \\
$\mathbf{1}$ yr & & & & & \\
Year & Random & 1 & 28.21 & 12.75 & $\mathbf{0 . 0 3 8}$ \\
Location & Fixed & 3 & 17.44 & 1.86 & 0.277 \\
Exposure (Location) & Fixed & 4 & 9.39 & 7.40 & $\mathbf{0 . 0 3 9}$ \\
Year $\times$ Location & Random & 3 & 2.21 & 1.74 & 0.296 \\
Year $\times$ Exposure (Location) & Random & 4 & 1.27 & 1.08 & 0.372 \\
Error & & 114 & 1.18 & & \\
\hline
\end{tabular}

\section{RESULTS}

\section{Brachyuran assemblage}

A total of 12 species belonging to 5 families of brachyuran decapods were identified when all study sites were considered together (Table 1). All species were identified to the species level except Taliepus spp. and Pinnixa spp., 2 complex genera whose taxonomy is still under discussion. These 2 genera were only represented in our samples by juveniles, which do not have well-developed diagnostic characters.

The 2 southernmost localities, Punta de Tralca and Hualpén, exhibited higher species richness, 10 and 11 species, respectively. Differences in species composition were detected at some localities, between exposed and protected sites, although this was variable. Caldera (northernmost locality) and Hualpén (southernmost locality) exhibited more species in protected sites, Guanaqueros had more species in exposed sites, and the number of species was the same in Punta de Tralca (Table 1).

\section{Physical variables}

The water column temperature, measured at the surface and bottom, at each site in the location of Hualpén showed a clear seasonal trend (Fig. 2A). The greatest difference between surface and bottom temperature occurred during the spring and summer months, indicating a stronger degree of stratification of the water column. However, and throughout the period considered, the protected site was always more stratified. During spring and summer of 2002 and 2003, the protected site was more stratified than during the same period of the following year (Fig. 2A). Likewise, southerly winds during the 2002 to 2003 period were comparatively stronger than during the following period (2003 to 2004) (Fig. 2B).

\section{Large-scale spatial and temporal variability in abundance of Paraxanthus barbiger}

The crab Paraxanthus barbiger was the most common and persistent species at all sites studied and exhibited the highest density within the brachyuran assemblage at most localities. The mean density of YOY for this species ranged between 0 and 10.2 ind. 


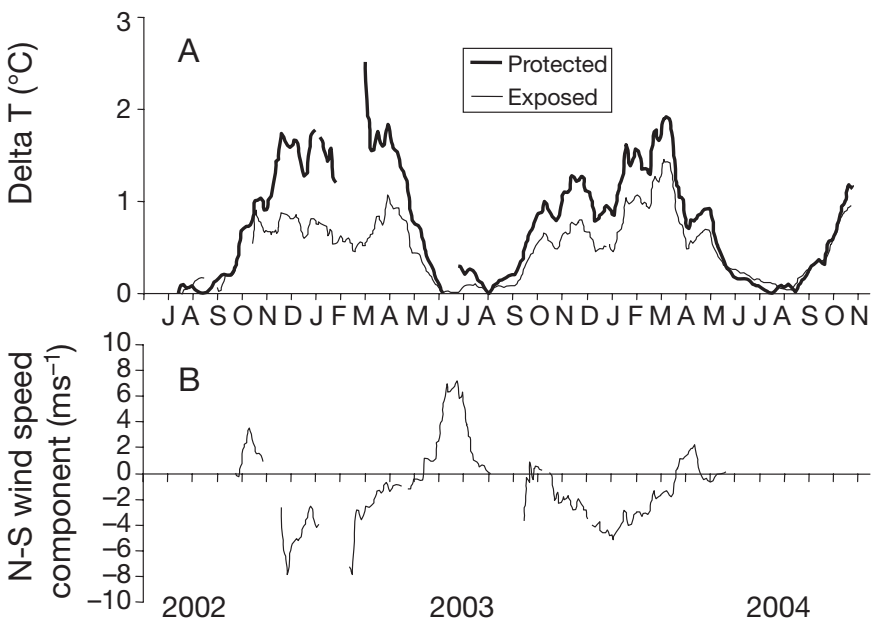

Fig. 2. Time series at Hualpén of: (A) temperature difference between bottom $(20 \mathrm{~m})$ and surface $(2 \mathrm{~m})$ for the protected and exposed sites and (B) north-south wind speed component measured at the tip of the peninsula. In both cases, data correspond to $6 \mathrm{~h}$ moving averages. Interrupted segments represent missing data due to lost of loggers or malfunction of the weather station

$\mathrm{m}^{-1}$ in Caldera, 7.9 and 33.1 ind. $\mathrm{m}^{-1}$ in Guanaqueros, 1.6 and 18.2 ind. $\mathrm{m}^{-1}$ in Punta de Tralca and 1.5 and 2.4 ind. $\mathrm{m}^{-1}$ in Hualpén. On the other hand, the mean density of $>1 \mathrm{yr}$ individuals varied between 1.4 and 8.8 ind. $\mathrm{m}^{-1}$ in Caldera, 5.9 and 28.8 ind. $\mathrm{m}^{-1}$ in Guanaqueros, 3.2 and 44.1 ind. $\mathrm{m}^{-1}$ in Punta de Tralca and 2.4 and 15.7 ind. $\mathrm{m}^{-1}$ in Hualpén. A comparison of the abundance between years for this species detected significant differences (Table 2). The analysis performed shows higher densities for 2003 compared with 2004, for both YOY and $>1$ yr groups (Table 2 ; p = 0.023 and 0.038 for YOY and $>1 \mathrm{yr}$, respectively). Although localities are separated by approximately $500 \mathrm{~km}$, significant differences were not observed among them in either year. However, within localities, significantly higher densities for individuals $>1$ yr were found at protected sites (Table 2). Newly settled individuals (YOY) were also significantly more abundant at 3 protected sites during 2003 and 1 in 2004 (locations with asterisks in Fig. 3), although results must be interpreted with caution since the interaction between year and exposure $(p=0.053)$ was not quite significant.

\section{Local-scale spatial and temporal variability in abundance of several brachyuran species}

High temporal variability in the abundance of benthic stages was observed for the 4 species quantified and obtained through monthly substrate-specific suction samples between May 2002 and June 2004 at Hualpén (Fig. 4). However, there is a general trend showing a seasonal pattern of recruitment (abundance of YOY), with highest values during austral spring and summer months (Fig. 4A, C,G). The only species that did not exhibit a seasonal pattern in a clear way was Gaudichaudia gaudichaudi, showing a moderately low level of new settlers throughout the sampling period (Fig. 4E). When the abundance pattern of YOY over time was compared between sites (degree of exposure), Cancer setosus, and to a lesser extent Paraxanthus barbiger, exhibited larger peaks of recruitment at the protected site relative to the exposed site (Fig. 4A,C). A similar but opposite pattern describes the YOY abundance of $G$. gaudichaudi, with greater abundance at the exposed site (Fig. 4E). The occurrence of significant interaction for the later species between the temporal factors (either year or month) and exposure allowed further pairwise comparisons that confirmed these results. This was not the case for newly settled individuals of Pilumnoides perlatus, where no significant interactions occurred (Fig. 4G). The abundance of individuals $>1$ yr was highly variable and did not show a distinctive temporal trend (Fig. 4B,D,F,H, Table 3). Similar to the YOY data, significant interactions occurred between exposure and the temporal factors (Table 3). Post hoc comparisons showed that $>1$ yr abundance of C. setosus and P. barbiger exhibited greater peaks at the protected
Fig. 3. Paraxanthus barbiger. Spatial and temporal variability in mean density $( \pm 1 \mathrm{SE})$ at exposed and protected sites in 4 locations along the Chilean coast during September and October (2003 and 2004, respectively). YOY: young-of-the-year; $>1 \mathrm{yr}$ : individuals $1 \mathrm{yr}$ and older. ${ }^{*}$ Significant differences of pairwise comparisons $(p<0.05)$ 


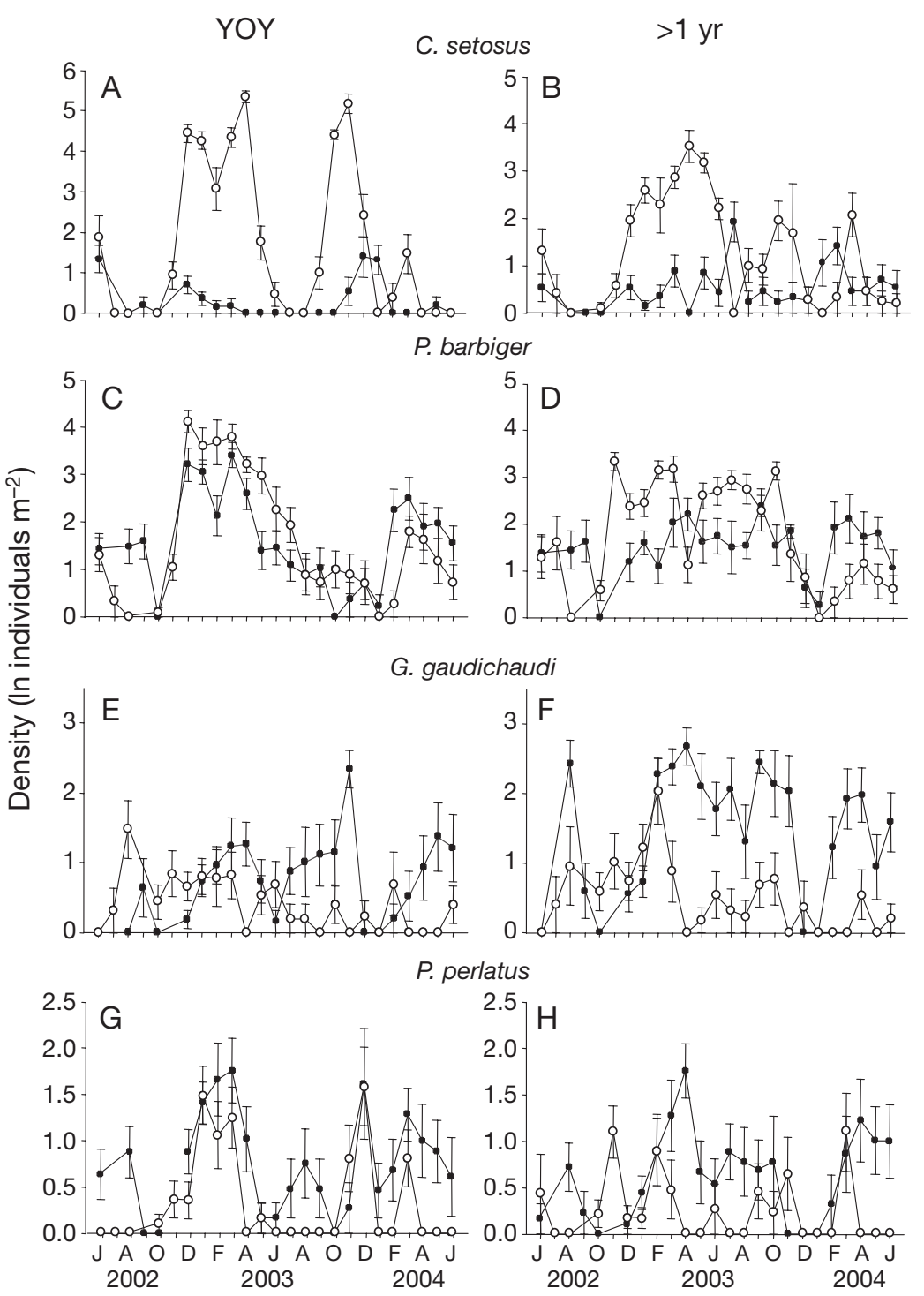

Fig. 4. Temporal (monthly) variability of mean density $( \pm 1 \mathrm{SE})$ of young-ofthe-year (YOY) and individuals older than 1 yr (>1yr) for 4 brachyuran species: $(\mathrm{A}, \mathrm{B})$ Cancer setosus; (C,D) Paraxanthus barbiger; (E,F) Gaudichaudia gaudichaudi; $(\mathrm{G}, \mathrm{H})$ Pilumnoides perlatus) at 2 contrasting sites ( $\bullet$ : exposed; $\circ$ : protected) at Hualpén between June 2002 and June 2004. Gaps correspond to months when samples were not obtained

site than at the exposed site (Fig. 4B, D). An opposite pattern described the $>1 \mathrm{yr}$ abundance of $G$. gaudichaudi and P. perlatus (Fig. 4F, H).

\section{Variability in abundance of competent larvae and early benthic stages at a local spatial scale}

Both, passive collectors in the water column and plankton surveys were useful for assessing the relative abundance of megalopae at each site in Hualpén and served to identify the temporal variability in the 3 most abundant species, Cancer setosus, Paraxanthus barbi- ger and Pilumnoides perlatus (Figs. 5, 6 \& 7). The artificial larval collectors deployed at 2 depths at each site exhibited a similar pattern of abundance over time, with 2 distinctive peaks during the spring and summer months between September 2002 and July 2004. Similarly, the presence of megalopae in the water column (plankton surveys), although variable, also described peaks of abundance around the same periods between 2002 and 2004. The lack of replicates for the plankton data did not allow further statistical comparisons. In general, and for the period considered, the occurrence of peaks of megalopae (in collectors and plankton; Figs. 5, 6 \& 7) corresponded to those detected for YOY on the bottom (Fig. 4). However, results of correlation analyses between the abundance of megalopae (at either depth) and YOY individuals on the bottom were only significant for C. setosus, with no time lag at either depth at the exposed site (surface: $\mathrm{r}_{\mathrm{S}}=0.659, \mathrm{p}=$ $0.0015 ; 10 \mathrm{~m}: \mathrm{r}_{\mathrm{S}}=0.563, \mathrm{p}=0.009$; surface $\left.+10 \mathrm{~m}: \mathrm{r}_{\mathrm{S}}=0.579, \mathrm{p}=0.007\right)$. On the other hand, when comparisons were made for each species between the monthly abundance of larvae that settled on collectors positioned at different depths and sites over the whole period from 2002 to 2004, the temporal factor (month) was the only one showing significant differences for all species; again, this points to the seasonal nature of competent larval supply (Table 4). Throughout the period, and on average, C. setosus megalopae settled at higher densities at $10 \mathrm{~m}$, although interaction with the temporal factor was also significant (Table 4, Fig. 5). The number of newly settled $P$. barbiger was not different for any of the spatial factors or interactions, a result that is probably explained by the low number of individuals of this species that utilized the artificial settlement substrate (Table 4, Fig. 6). However, the settlement of $P$. perlatus exhibited significant differences for all single factors and their interactions, where a strong seasonality was evident and also, on average, a higher density of settlers at the protected site. The significant differences in settlement at different depths arise from the different magnitudes of these values at each site and from the lags in abundance peaks between sites, settlement being 1 to 2 mo earlier at the exposed site (Table 4, Fig. 7). 
Table 3. F-ratios and probabilities from nested ANOVAs for differences in mean densities of young-of-the-year (YOY) and individualas older than $1 \mathrm{yr}$ (>1 yr) of 4 brachyuran species among years (2002 to 2004), months and contrasting exposure sites at Hualpén. For the sake of space only $F$ - and p-values are shown. Bold: significant $p$-values

\begin{tabular}{|c|c|c|c|c|c|c|c|c|}
\hline \multirow[t]{2}{*}{ Source of variation } & \multicolumn{2}{|c|}{ Cancer setosus } & \multicolumn{2}{|c|}{$\begin{array}{c}\text { Paraxhantus } \\
\text { barbiger }\end{array}$} & \multicolumn{2}{|c|}{$\begin{array}{l}\text { Gaudichaudia } \\
\text { gaudichaudi }\end{array}$} & \multicolumn{2}{|c|}{$\begin{array}{c}\text { Pilumnoides } \\
\text { perlatus }\end{array}$} \\
\hline & $F$ & $\mathrm{p}$ & $F$ & $\mathrm{p}$ & $F$ & $\mathrm{p}$ & $F^{1}$ & $\mathrm{p}$ \\
\hline \multicolumn{9}{|l|}{ YOY } \\
\hline Year & 0.594 & 0.626 & 1.432 & 0.321 & 0.675 & 0.632 & 0.902 & 0.427 \\
\hline Month (Year) & 1.381 & 0.241 & 10.967 & $<0.001$ & 0.484 & 0.948 & 6.125 & $<0.001$ \\
\hline Exposure & 1.960 & 0.303 & 0.033 & 0.873 & 1.108 & 0.423 & 16.935 & 0.113 \\
\hline Year $\times$ Exposure & 6.961 & 0.005 & 12.339 & $<0.001$ & 2.821 & 0.083 & 1.019 & 0.378 \\
\hline Exposure $\times$ Month (Year) & 18.663 & $<0.001$ & 1.281 & 0.192 & 3.139 & $<0.001$ & 1.040 & 0.413 \\
\hline \multicolumn{9}{|l|}{$>1 \mathrm{yr}$} \\
\hline Year & 0.919 & 0.535 & 2.237 & 0.288 & 1.801 & 0.413 & 0.761 & 0.632 \\
\hline Month (Year) & 0.536 & 0.919 & 1.995 & 0.067 & 0.926 & 0.574 & 1.060 & 0.453 \\
\hline Exposure & 1.323 & 0.375 & 0.071 & 0.816 & 8.242 & 0.137 & 11.359 & 0.192 \\
\hline Year $\times$ Exposure & 7.519 & 0.004 & 7.935 & 0.003 & 1.708 & 0.207 & 0.672 & 0.522 \\
\hline Exposure $\times$ Month (Year) & 5.399 & $<0.001$ & 2.205 & 0.003 & 4.339 & $<0.001$ & 3.030 & $<0.001$ \\
\hline
\end{tabular}

Table 4. Full factorial ANOVAs for differences in mean densities of young-ofthe-year (YOY) individuals of 3 brachyuran species settled on artificial collectors. Data correspond to monthly averages (between September 2002 and July 2004) obtained from collectors positioned at different depths and sites of contrasting exposure at Hualpén. Bold: significant p-values

\begin{tabular}{|lrrrr|}
\hline Source of variation & df & MS & $F$ & $\mathrm{p}$ \\
\hline Cancer setosus & & & & \\
Month & 21 & 0.794 & 14.301 & $\mathbf{< 0 . 0 0 0 1}$ \\
Exposure & 1 & 0.116 & 2.093 & 0.148 \\
Depth & 1 & 0.302 & 5.437 & $\mathbf{0 . 0 1 9}$ \\
Month $\times$ Exposure & 20 & 0.057 & 1.033 & 0.418 \\
Month $\times$ Depth & 21 & 0.199 & 3.597 & $<\mathbf{0 . 0 0 0 1}$ \\
Exposure $\times$ Depth & 1 & 0.087 & 1.575 & 0.209 \\
Month $\times$ Exposure $\times$ Depth & 19 & 0.081 & 1.459 & 0.092 \\
Error & 885 & 0.055 & & \\
Paraxanthus barbiger & & & & \\
Month & 21 & 0.042 & 2.028 & $\mathbf{0 . 0 0 4}$ \\
Exposure & 1 & 0.027 & 1.293 & 0.255 \\
Depth & 1 & 0.009 & 0.448 & 0.503 \\
Month $\times$ Exposure & 20 & 0.016 & 0.772 & 0.749 \\
Month $\times$ Depth & 21 & 0.014 & 0.673 & 0.861 \\
Exposure $\times$ Depth & 1 & 0.002 & 0.105 & 0.746 \\
Month $\times$ Exposure $\times$ Depth & 19 & 0.012 & 0.609 & 0.902 \\
Error & 885 & 0.021 & & \\
Pilumnoides perlatus & & & & \\
Month & 21 & 7.861 & 36.681 & $\mathbf{< 0 . 0 0 0 1}$ \\
Exposure & 1 & 2.463 & 11.495 & $\mathbf{0 . 0 0 1}$ \\
Depth & 1 & 2.639 & 12.316 & $<\mathbf{0 . 0 0 0 1}$ \\
Month $\times$ Exposure & 20 & 0.759 & 3.540 & $\mathbf{< 0 . 0 0 0 1}$ \\
Month $\times$ Depth & 21 & 0.861 & 4.017 & $\mathbf{< 0 . 0 0 0 1}$ \\
Exposure $\times$ Depth & 1 & 4.548 & 21.221 & $\mathbf{< 0 . 0 0 0 1}$ \\
Month $\times$ Exposure $\times$ Depth & 19 & 1.212 & 5.654 & $\mathbf{0 . 0 0 0 1}$ \\
Error & 885 & 0.214 & & \\
\hline
\end{tabular}

The pooled YOY abundance of Cancer setosus that settled on the bottom was significantly greater at the protected site compared to the exposed site $\left(F_{1,28}=8.468, \mathrm{p}<0.001\right.$; Fig. 8$)$, while Paraxanthus barbiger exhibited no difference $\left(F_{1,28}=1.197, \mathrm{p}=0.174\right.$; Fig. 9) and was slightly greater for Pilumnoides perlatus $\left(F_{1,28}=1.466\right.$, $\mathrm{p}=0.052$; Fig. 10). No net significant difference was detected between the abundance of megalopae of C. setosus settling on collectors at either site or depth, although results should be viewed with caution since the interaction between these factors is only marginally not significant (Table 5). The abundance of $P$. perlatus that settled at different depths was not significantly different among dates; however, the average number of settlers at the protected site were slightly greater $(p=0.066)$ than at the exposed site (Table 5, Fig. 10). Similar analysis was not performed for $P$. barbiger, since settlement on collectors for this species was very minor during January (only 1 megalopae found at the $10 \mathrm{~m}$ collector at the exposed site on Day 19).

\section{DISCUSSION}

The simultaneous high-frequency sampling of meand YOYs settling inside bottom collectors at each site at Hualpén during January 2004 exhibited important variation among dates (Figs. 8, 9 \& 10).
We recorded and compared the abundance of different ontogenetic stages of several common species of brachyuran decapods at 4 localities covering a consid- 


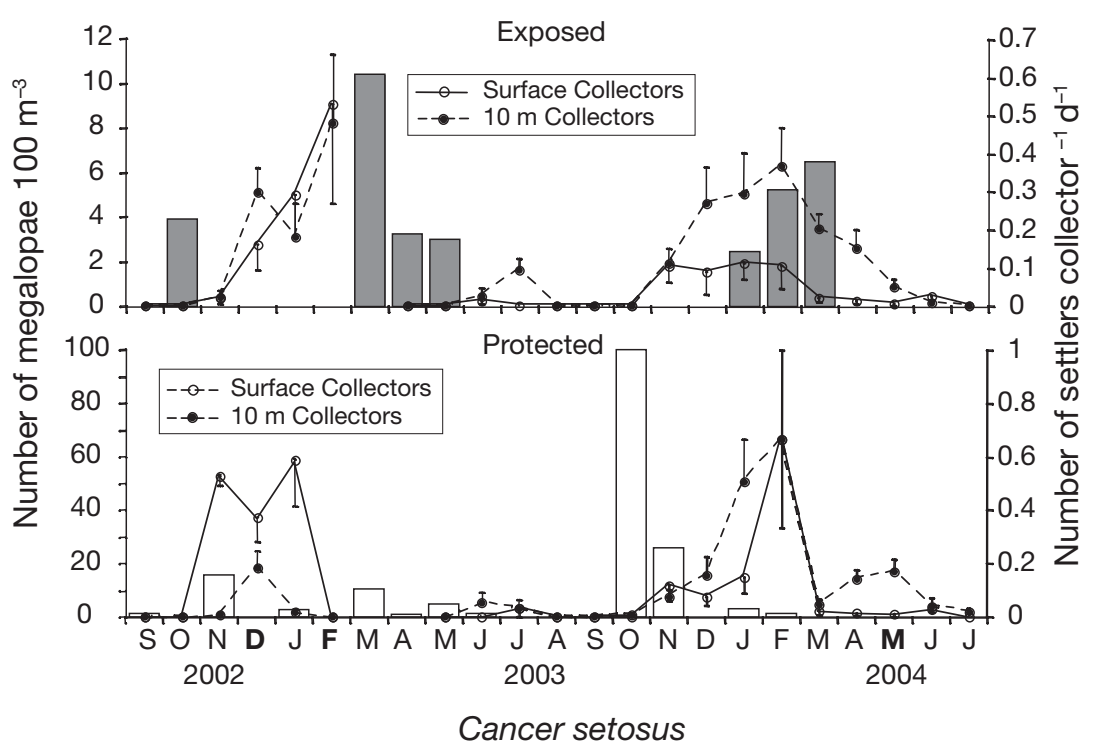

Fig. 5. Cancer setosus. Monthly abundance $( \pm 1 \mathrm{SE})$ of megalopae in the water column (bars) and abundance of newly settled megalopae in collectors installed at 2 depths (o: 4 at the surface; $\bullet: 4$ at $10 \mathrm{~m}$ ) between September 2002 and July 2004 at the exposed and protected sites at Hualpén. Bold letters correspond to months when plankton was not collected. Collector data were not obtained during March 2003 at the exposed site and during March and April 2003 at the protected site. For the sake of clarity only half of the error bars were drawn for each collector value

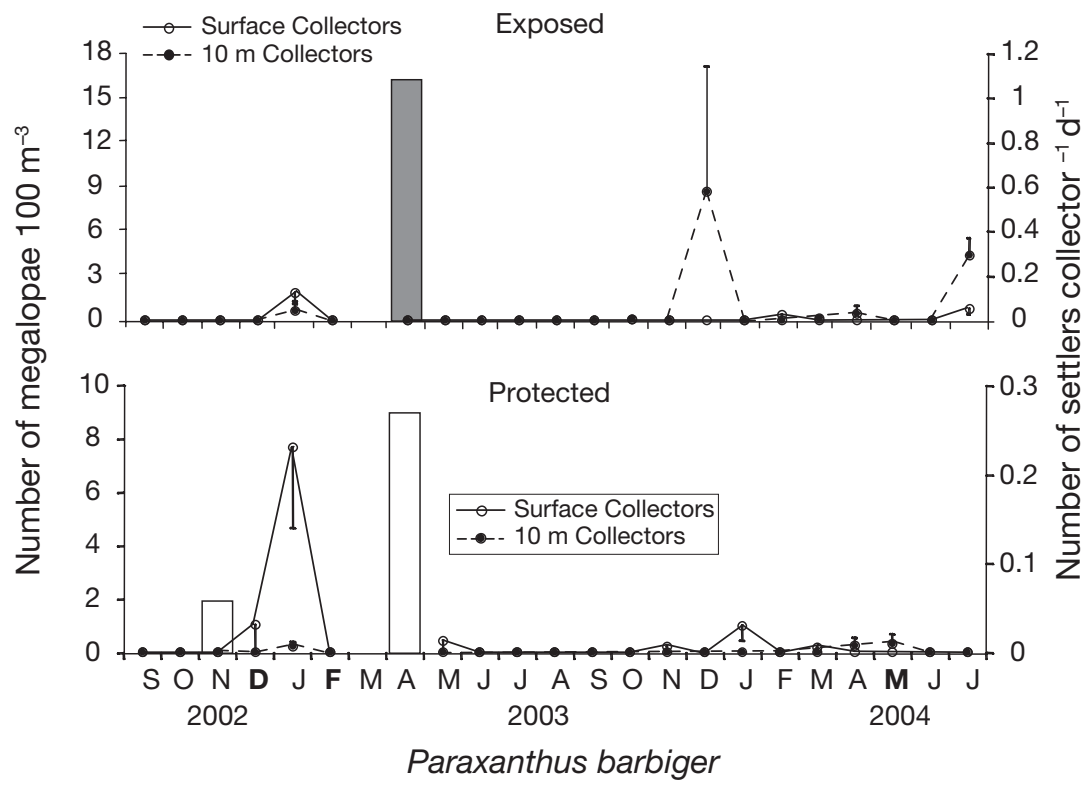

Fig. 6. Paraxanthus barbiger. Monthly abundance $( \pm 1 \mathrm{SE})$ of megalopae in the water column (bars) and abundance of newly settled megalopae in collectors installed at 2 depths (o: 4 at the surface; •: 4 at 10 m) between September 2002 and July 2004 at the exposed and protected sites at Hualpén. Bold letters correspond to months when plankton was not collected. Collector data were not obtained during March 2003 at the exposed site and during March and April 2003 at the protected site. For the sake of clarity only half of the error bars were drawn for each collector value erable stretch $(<1000 \mathrm{~km})$ of coastline along central Chile. Further, more detailed surveys, both in frequency and intensity, were implemented at 1 of the study locations. The main factor considered for the selection of locations had to do with the existence of a peninsula with sites (exposed and protected) on either side. This design originated from the general working hypothesis of this study stating that irregularities along the coast line (i.e. exposed vs. protected sides of a peninsula) represent scenarios that will generate differences in the amount of larvae that will arrive, and possibly settle, this being greater at protected sites. Although sites within each location were only hundreds of meters apart, important differences in water column temperature were evident. Throughout the study, at the southernmost location (Hualpén), water column stratification was greater at the protected site. This was particularly noticeable during the spring and summer months, periods dominated by southerly winds when most brachyuran competent larvae were present. Thus, and although yet unknown, it is likely that differences in the amount of competent larvae near the shore between these sites would be linked to physical mechanisms associated with those differences (Wing et al. 1998).

Our large-scale surveys of newly settled (YOY) and of older recruits ( $>1 \mathrm{yr}$ ) of Paraxanthus barbiger at 4 different locations and for 2 consecutive years showed that in most cases (3 in 2003 and 1 in 2004) YOY abundance was greater at the protected sites, while this was always the case for $>1$ yr individuals, even though samples were collected hundreds of kilometers apart. Furthermore, YOY and >1 yr individuals were, on average, more abundant during 2003 compared with 2004. Hence, the presence of headlands together with the occurrence of some regional-scale factor involving shoreward supply of larvae might have to be considered in order to explain the former pattern. Given the assumption of some level of coupling between larval abundance and that of recruits, our 


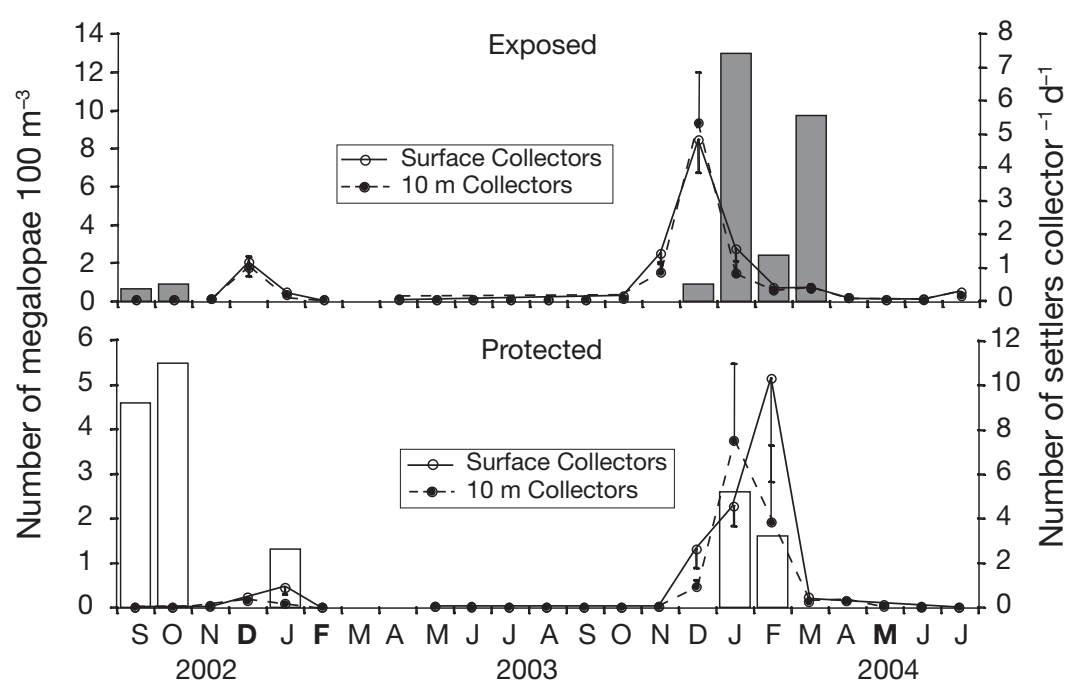

Pilumnoides perlatus

Fig. 7. Pilumnoides perlatus. Monthly abundance $( \pm 1 \mathrm{SE})$ of megalopae in the water column (bars) and abundance of newly settled megalopae in collectors installed at 2 depths (o: 4 at the surface; $\bullet$ : 4 at $10 \mathrm{~m}$ ) between September 2002 and July 2004 at the exposed and protected sites at Hualpén. Bold letters correspond to months when plankton was not collected. Collector data were not obtained during March 2003 at the exposed site and during March and April 2003 at the protected site. For the sake of clarity only half of the error bars were drawn for each collector value

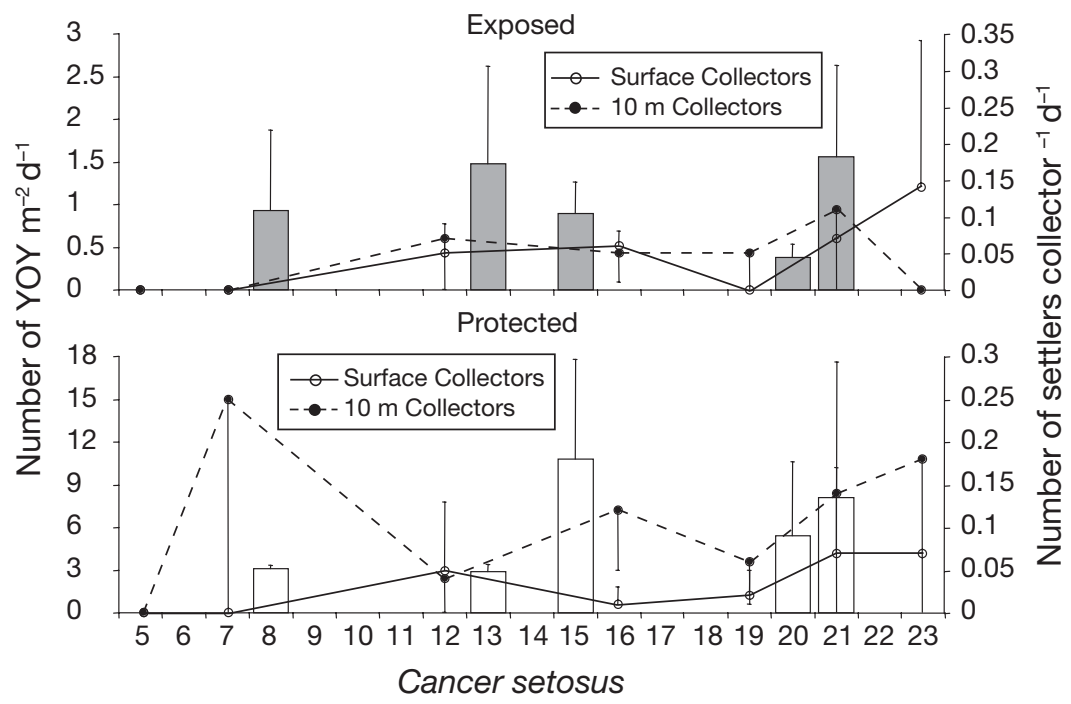

Fig. 8. Cancer setosus. Abundance ( $\pm 1 \mathrm{SD}$ ) of newly settled (YOY) individuals inside artificial bottom collectors (bars) and abundance of newly settled megalopae in collectors installed at 2 depths (o: 4 at the surface; $\bullet: 4$ at $10 \mathrm{~m}$ ) during January 2004 at the exposed and protected sites at Hualpén. For the sake of clarity only half of the error bars were drawn for each collector value

results agree with previous findings according to which shoreline configuration plays a role in the distribution and abundance of meroplankton and holoplankton (Murdoch 1989, Archambault et al. 1998,
Archambault \& Bourget 1999, McCulloch \& Shanks 2003, Shanks et al. 2003).

Similar surveys, performed on a monthly basis at the southernmost location (Hualpén), where 4 brachyuran species were abundant enough to allow valid comparisons over time, showed that 2 species (Cancer setosus and Paraxanthus barbiger) exhibited a pattern similar to the one described before for $P$. barbiger at a regional scale. For these 2 species, and specifically during the 2 spring to summer periods, newly settled individuals (YOY) were, on average, more abundant at the protected site. The result of the nested ANOVA highlights the significant interaction between the spatial and temporal factors, monthly and seasonal for $P$. barbiger and only seasonal for C. setosus. A similar pattern was not detected for the other 2 less abundant species (Gaudichaudia gaudichaudi and Pilumnoides perlatus). These species showed a less pronounced seasonal pattern of recruitment, although a significant difference was detected in the settlement signal of $P$. perlatus on a monthly basis. The significant interaction between exposure and one of the temporal factors (month) in G. gaudichaudi could explain the greater YOY abundance at the exposed site during the second settlement period. The general pattern of $>1$ yr abundance of these 4 species was similar to that of YOY and also highly variable, explained by the significant interaction between one of the temporal factors (month) and exposure. Additionally, the abundance of $C$. setosus and P. barbiger was seasonally greater at the protected site and exhibited significant interaction between the temporal factor (year) and exposure.

We were able to obtain an early signal of competent larvae (megalopae) availability for 3 of the species in Hualpén using 2 different methods, namely plankton net tows and artificial settlement collectors positioned at 2 different depths. Our monthly plankton net tows provided a snapshot of the water column abundance of larvae, and, although competent larvae were collected during the identified settlement 


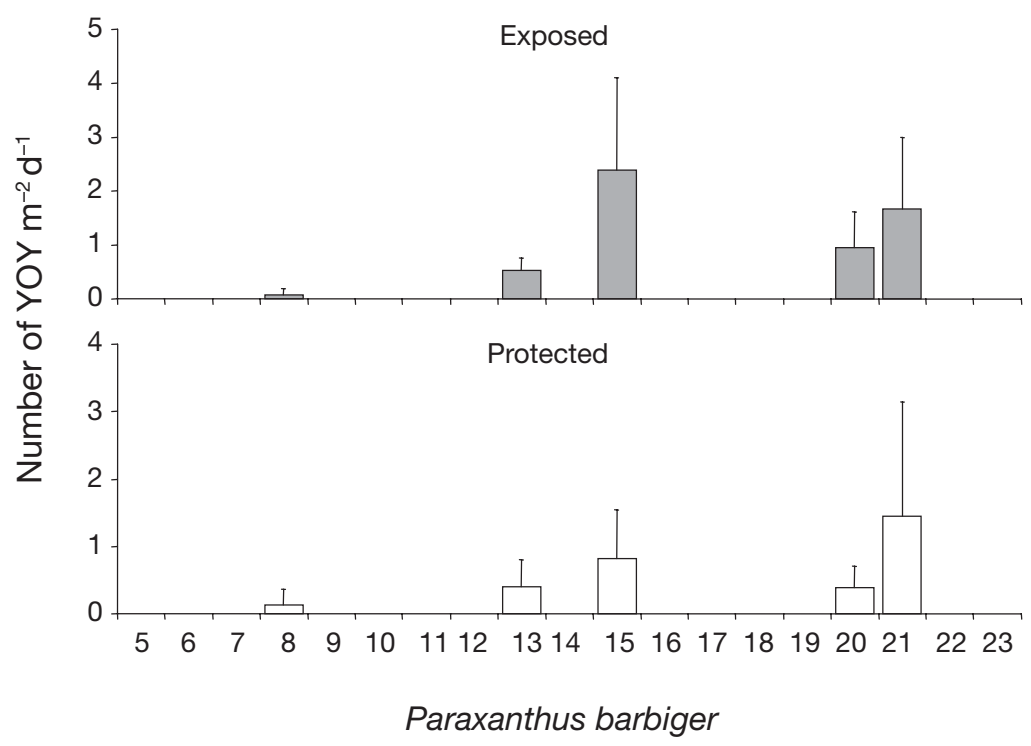

Fig. 9. Paraxanthus barbiger. Abundance ( \pm 1 SD) of newly settled (YOY) individuals inside artificial bottom collectors during January 2004 at the exposed and protected sites at Hualpén

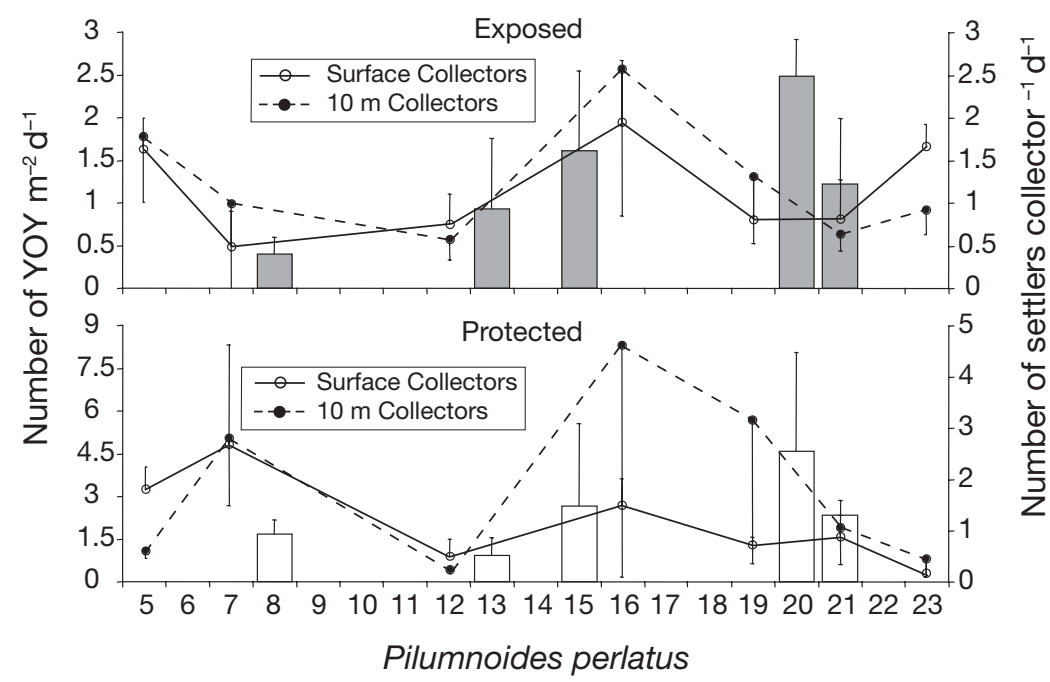

Fig. 10. Pilumnoides perlatus. Abundance ( $\pm 1 \mathrm{SD})$ of newly settled (YOY) individuals inside artificial bottom collectors (bars) and abundance of newly settled megalopae in collectors installed at 2 depths (o: 4 at the surface; $\bullet: 4$ at $10 \mathrm{~m}$ ) during January 2004 at the exposed and protected sites at Hualpén. For the sake of clarity only half of the error bars were drawn for each collector value

sites and times for each species. Equivalent artificial settlement substrates have been successfully utilized for quantifying brachyuran larvae (Moksnes \& Wennhage 2001, Vargas et al. 2004). The temporal variability in the abundance of megalopae exhibited a strong seasonal pattern that corresponded well with YOY abundance. However, when the monthly abundance of megalopae, and that of YOY individuals at each site (protected or exposed), were subjected to a correlation analysis for the whole time period, only Cancer setosus showed a significant relationship. The general lack of correlation was surprising, particularly since collectors were located directly next to the area where bottom suction sample surveys were performed. However, it is important to recognize that the larval supply signal, quantified through YOY abundance along the bottom, might be obliterated due to important losses soon after settlement. Such important post-settlement mortality has been shown for several other brachyuran species (i.e. Eggleston \& Armstrong 1995, Palma et al. 1998, Moksnes 2004). Additionally, the propensity of specific larvae to settle into these artificial collectors may also vary. Therefore, our results and interpretation regarding the coupling between the local abundance of competent larvae, quantified on artificial collectors positioned in the water column, and the density of recently settled individuals on natural substrata must be considered with caution.

Given the possibility that some of the measured differences in the abundance of newly settled individuals at Hualpén were due to differences in the type of bottom substrate available at each site, the results of the experiment in which standardized substrate was utilized suggests that this is not the case. For at least 1 of the species con-

period (spring to summer), they poorly represented the average larval supply and settlement in the assessed nursery area. Similar difficulties have also been reported for other brachyuran species (Moksnes \& Wennhage 2001). Given the artificial nature of the collectors and the differential attractiveness they might represent for each species, this only represents a relative measure of their abundance, which is nonetheless comparable between sidered (Cancer setosus), YOY abundance was significantly higher inside collectors installed at the protected site, a result that corresponds to the greater YOY abundance obtained from natural substrata at the protected site throughout the study. These results, however, should again be viewed with caution, since the deployment of the bottom collectors occurred during January 2004, one of the periods of lowest natural 
Table 5. ANOVAs for differences in mean densities of megalopae of Cancer setosus and Pilumnoides perlatus that settled on artificial collectors at different depths and sites of contrasting exposure during January 2004 in Hualpén

\begin{tabular}{|lrccc|}
\hline Source of variation & df & MS & $F$ & $\mathrm{p}$ \\
\hline Cancer setosus & & & & \\
Exposure & 1 & 0.047 & 1.421 & 0.237 \\
Depth & 1 & 0.079 & 2.385 & 0.126 \\
Exposure $\times$ Depth & 1 & 0.126 & 3.767 & 0.055 \\
Error & 80 & 0.033 & & \\
Pilumnoides perlatus & & & & \\
Exposure & 1 & 0.936 & 3.466 & 0.066 \\
Depth & 1 & 0.116 & 0.429 & 0.514 \\
Exposure $\times$ Depth & 1 & 0.073 & 0.271 & 0.604 \\
Error & 80 & 0.270 & & \\
\hline
\end{tabular}

In summary, our study represents a multi-scale approach that should draw attention toward viewing coastal areas, and their naturally occurring irregularities, as complex systems influencing the ecology of species undergoing settlement and recruitment. In this context, the current study represents an effort to describe the potentially important effect of coastline configurations on the ecological patterns of several common coastal invertebrates along temperate coasts. With the sole exception of early larval stages (zoea), we considered the variation in abundance of different ontogenetic stages of sevabundance of YOY recorded for any of the species considered throughout this study (see Fig. 4A, C,E,G).

On average, $>1 \mathrm{yr}$ individuals of Cancer setosus and Paraxanthus barbiger exhibited greater seasonal abundance between 2002 and 2004, a pattern that corresponded to the one displayed by YOY individuals during the same period. The fact that for these species the early signal of benthic abundance remained in older segments of the local population could be interpreted as a case of recruitment limitation (sensu Doherty \& Fowler 1994). Although variations in the rates of larval delivery toward coastal settings have been reported to be the factor behind the local patterns of abundance of other species of decapod crustaceans (i.e. Pearse \& Phillips 1988, Heck et al. 2001), our results do not clearly show the existence of such a relationship between larval supply rates and that of newly settled individuals. Our evidence suggests that this might be the case only for $C$. setosus.

In the present study we did not specifically examined the potential larval transport mechanisms involved, although we speculate on how the ecological pattern described here might result from interaction with physical features such as coastal irregularities (Archambault \& Bourget 1999). We propose that, at least for Cancer setosus and Paraxanthus barbiger, longer retention times at protected sites (Okubo 1973, Signell \& Geyer 1991, Graham \& Largier 1997, Wing et al. 1998) may provide a mechanism driving the pattern of elevated YOY abundance at the protected site. Similar dynamics, associated with the occurrence of intermittent upwelling circulation, were observed to have a strong effect on the settlement (Wing et al. 1995) and the retention (Wing et al. 1998) of crab megalopae on the lee side of Point Reyes peninsula, California. Retention of zooplankton in nearshore areas has also been associated with the occurrence of upwelling shadows, structures that form near promontories during upwelling conditions (Graham \& Largier 1997). eral crab species separately. This is an important point, since these stages are subject to different sources of variability, mostly physical before larvae settle to predominantly biological interactions after settlement has occurred. Furthermore, and bearing in mind the broad range of distribution of organisms like decapod crustaceans, it is likely that coastal irregularities will have a significant impact on their local abundance via modulating the rates of recruitment. Our study focuses on a subject that has guided recent research efforts aiming to understand the effect, at multiple spatial and temporal scales, of physical factors affecting recruitment (Botsford 2001), as well as the degree of variability of biological interactions on the benthos at those scales (Menge et al. 2004). These findings underscore the understanding the role of pre- and post-settlement processes (Peterson \& Estes 2001). This study not only contributes to the field of benthic ecology, but also provides useful information for informed decisions on the management and conservation of brachyuran decapods, a group of organisms that supports an extensive fishery along the Chilean coast (Fernández \& Castilla 1997).

Finally, we stress the need to further investigate the nature of transport mechanisms associated with shoreline configurations, together with post-settlement processes in generating spatial patterns of demography.

Acknowledgements. We thank the enthusiastic field and laboratory assistance of E. Poulin, R. San Martín, F. Ogalde, R. Wells and C. Inostrosa. We also thank 'Moroco' for his help with the field work on board the 'Don Niba' and for the facilities in Lenga. Discussions on these subjects with J. Pineda, while visiting his laboratory, were particularly helpful. The manuscript substantially benefited from the comments provided by $\mathrm{R}$. Wahle and by 3 anonymous reviewers. This research was supported by Grant FONDECYT 1020499 and Fundación Andes-Universidad de Concepción-Woods Hole importance to conservation and management of 
Oceanographic Institution fellowship to A.T.P. and by FONDAP Grant 1501-001 Program 5 to the Center for Advanced Studies in Ecology and Biodiversity to F.P.O.

\section{LITERATURE CITED}

Archambault P, Bourget E (1999) Influence of shoreline configuration on spatial variation of meroplanktonic larvae, recruitment and diversity of benthic subtidal communities. J Exp Mar Biol Ecol 241:309-333

Archambault P, Roff JC, Bourget E, Bang B, Ingram GR (1998) Nearshore abundance of zooplankton in relation to shoreline configuration and mechanisms involved. J Plankton Res 20:671-690

Armsworth PR (2002) Recruitment limitation, population regulation, and larval connectivity in reef fish metapopulations. Ecology 83:1092-1104

Boicourt WC (1988) Estuarine larval retention mechanisms on two spatial scales. In: Kennedy VS (ed) Estuarine comparisons. Academic Press, New York, p 445-458

Botsford LW (2001) Physical influences on recruitment to California Current invertebrate populations on multiple scales. ICES J Mar Sci 58:1081-1091

Carr MH, Hixon MA (1995) Predation effects on early postsettlement survivorship of coral-reef fishes. Mar Ecol Prog Ser 124:31-42

Castilla JC (1981) Perspectivas de investigación en estructura y dinámica de comunidades intermareales rocosas de Chile central. II. Depredadores de alto nivel trófico. Medio Ambiente 5(1-2):190-215

Connolly SR, Roughgarden J (1998) A latitudinal gradient in northeast Pacific intertidal community structure: evidence for an oceanographically based synthesis of marine community theory. Am Nat 151:311-326

Connolly SR, Roughgarden J (1999) Increased recruitment of northeast Pacific barnacles during the 1997 El Niño. Limnol Oceanogr 44:466-469

Cronin TW, Forward RB (1982) Tidally timed behavior: effects on larval distribution in estuaries. In: Kennedy VS (ed) Estuarine comparisons. Academic Press, New York, p 505-521

Delany J, Myers AA, McGrath D, O'Riordan RM, Power AM (2003) Role of post-settlement and 'supply-side' ecology in setting patterns of intertidal distribution in the chthamalid barnacles Chthamalus montagui and C. stellatus. Mar Ecol Prog Ser 249:207-214

Doherty PJ, Fowler T (1994) An empirical test of recruitment limitation in a coral reef fish. Science 263:935-939

Doherty PJ, Dufour V, Galzin R, Hixon MA, Meekan MG, Planes S (2004) High mortality during settlement is a population bottleneck for a tropical surgeonfish. Ecology 85: 2422-2428

Eggleston DB, Armstrong DA (1995) Pre- and post-settlement determinations of estuarine Dungeness crab recruitment. Ecol Monogr 65 (2):193-216

Elner RW, Campbell A (1991) Spatial and temporal patterns in recruitment for American lobster, Homarus americanus, in the northwestern Atlantic. Mem Qld Mus 31:349-363

Fariña JM, Ojeda FP (1993) Abundance, activity, and trophic patterns of the redspotted catshark, Schroederichthys chilensis, on the Pacific temperate coast of Chile. Copeia 2:545-549

Fernández M, Castilla JC (1997) The Chilean artisanal stone crab (Homalaspis plana) fishery: catch trends in open access zones and the effect of management areas in central Chile. J Shellfish Res 16:371-377
Forrester GE (1995) Strong density-dependent survival and recruitment regulate the abundance of a coral reef fish. Oecologia 103:275-282

Gaines S, Roughgarden J (1985) Larval settlement rate: a leading determinant of structure in an ecological community of the marine intertidal zone. Proc Natl Acad Sci USA 82:3707-3711

Garland ED, Zimmer CA, Lentz SJ (2002) Larval distributions in inner-shelf waters: the roles of wind-driven cross-shelf currents and diel vertical migrations. Limnol Oceanogr 47 : 803-817

Govoni JJ, Pietrafesa LJ (1994) Eulerian views of layered water currents, vertical distribution of some larval fishes, and inferred advective transport over the continental shelf off North Carolina, USA, in winter. Fish Oceanogr 3(2):120-132

Graham WM, Largier JL (1997) Upwelling shadows as nearshore retention sites: the examples of northern Monterey Bay. Cont Shelf Res 17:509-532

Heck KL, Coen LD, Morgan SG (2001) Pre- and postsettlement factors as determinants of juvenile blue crab Callinectes sapidus abundance: results from the northcentral Gulf of Mexico. Mar Ecol Prog Ser 222:163-176

Hughes TP, Baird AH, Dinsdale EA, Moltschaniwskyj NA, Pratchett MS, Tanner JE, Willis BL (1999) Patterns of recruitment and abundance of corals along the Great Barrier Reef. Nature 397:59-63

Jenkins GP, Black KP, Wheatley MJ, Hatton DN (1997) Temporal and spatial variability in recruitment of temperate, seagrass-associated fish is largely determined by physical processes in the pre- and post-settlement phases. Mar Ecol Prog Ser 148:23-35

Lancellotti DA, Vasquez JA (2000) Zoogeografía de macroinvertebrados bentónicos de la costa de Chile: contribución para la conservación marina. Rev Chil Hist Nat 73:99-129

Lobel PS, Robinson AR (1986) Transport and entrapment of fish larvae by ocean mesoscale eddies and currents in Hawaiian waters. Deep-Sea Res 33:483-500

McConaugha JR (1992) Decapod larvae: dispersal, mortality, and ecology. A working hypothesis. Am Zool 32:512-523

McCulloch A, Shanks AL (2003) Topographically generated fronts, very nearshore oceanography and the distribution and settlement of mussel larvae and barnacle cyprids. J Plankton Res 25:1427-1439

Menge BA, Blanchette C, Raimondi P, Freidenburg T and 6 others (2004) Species interaction strength: testing model predictions along an upwelling gradient. Ecol Monogr 74: 663-684

Minchinton TE, Scheibling RE (1991) The influence of larval supply and settlement on the population structure of barnacles. Ecology 72:1867-1879

Miron B, Boudreau B, Bourget E (1995) Use of larval supply in benthic ecology: testing correlations between larval supply and larval settlement. Mar Ecol Prog Ser 124:301-305

Moksnes PO (2004) Self-regulating mechanisms in cannibalistic populations of juvenile shore crabs Carcinus meanas. Ecology 85:1343-1354

Moksnes PO, Wennhage H (2001) Methods for estimating decapod larval supply and settlement: importance of larval behavior and development stages. Mar Ecol Prog Ser 209:257-273

Murdoch RC (1989) The effects of headland eddy on surface macro-zooplankton assemblages north of Otago Peninsula, New Zealand. Estuar Coast Mar Sci 29:361-383

Ojeda FP, Fariña JM (1996) Temporal variations in the abundance, activity, and trophic patterns of the rockfish, Sebastes capensis, off the central Chilean coast. Rev Chil Hist Nat 69:205-211 
Okubo A (1973) Effect of shoreline irregularities on streamwise dispersion in estuaries and other embayments. Neth J Sea Res 6:213-224

Palma AT, Ojeda FP (2002) Abundance, distribution and feeding patterns of a temperate reef fish in subtidal environments of the Chilean coast: the importance of understory algal turf. Rev Chil Hist Nat 75:189-200

Palma AT, Steneck RS (2001) Does variable coloration in juvenile marine crabs reduce risk of visual predation? Ecology 82:2961-2967

Palma AT, Wahle RA, Steneck RS (1998) Different early postsettlement strategies between American lobsters Homarus americanus and rock crabs Cancer irroratus in the Gulf of Maine. Mar Ecol Prog Ser 162:215-225

Palma AT, Steneck RS, Wilson CJ (1999) Settlement-driven, multiscale demographic patterns of large benthic decapods in the Gulf of Maine. J Exp Mar Biol Ecol 241: 107-136

Palma AT, Orrego C, Arraigada M (2003) Crypsis in early benthic phases of brachyuran decapod crustaceans in central Chile. Rev Chil Hist Nat 76:149-156

Pearse AF, Phillips BF (1988) ENSO events, the Leeuwin Current, and larval recruitment of the western rock lobster. ICES J Mar Sci 45:13-21

Peterson CH, Estes JA (2001) Conservation and management of marine communities. In: Bertness MD, Gaines SD, Hay ME (eds) Marine community ecology. Sinauer Associates, Sunderland, MA, p 469-507

Pineda J (1999) Circulation and larval distribution in internal tidal bore warm fronts. Limnol Oceanogr 44:1400-1414

Pineda J (2000) Linking larval settlement to larval transport: assumptions, potentials, and pitfalls. In: Farber-Lorda J (ed) Oceanography of the eastern Pacific. CICESE, Ensenada, p 84-105

Poulin E, Palma A, Leiva G, Hernández E, Martinez P, Navarrete S, Castilla JC (2002) Temporal and spatial variation in the distribution of premetamorphic larvae of Concholepas concholepas (Gastropoda: Muricidae) along the central coast of Chile. Mar Ecol Prog Ser 229:95-104

Roughgarden J, Gaines S, Possingham H (1988) Recruitment dynamics in complex life cycles. Science 241:1460-1466

Sale PF (1999) Recruitment in space and time. Nature 397: $25-26$

Shanks AL, Largier J, Brink L, Brubaker J, Hooff R (2000) Demonstration of the onshore transport of larval invertebrates by shoreward movement of an upwelling front. Limnol Oceanogr 45:230-236

Shanks AL, McCullogh A, Miller J (2003) Topographically generated fronts, very nearshore oceanography and the

Editorial responsibility: Kenneth L. Heck, Jr. (Contributing Editor), Dauphin Island, Alabama, USA distribution of larval invertebrates and holoplankters. J Plankton Res 25:1251-1277

Shkedy Y, Roughgarden J (1997) Barnacle recruitment and population dynamics predicted from coastal upwelling. Oikos 80:487-498

Signell RP, Geyer WR (1991) Transient eddy formation around headlands. J Geophys Res 96:2561-2575

Sokal RR, Rohlf FJ (1995) Biometry, 3rd edn. Freeman, San Francisco, CA

Sulkin SD, van Heukelem W (1982) Larval recruitment in the crab Callinectes sapidus Rathbyn: an amendment to the concept of larval retention in estuaries. In: Kennedy VS (ed) Estuarine comparisons. Academic Press, New York, p 459-475

Thiébaut E, Dauvin J-C, Lagadeuc Y (1994) Horizontal distribution and retention of Owenia fusiformis larvae (Annelida: Polychaeta) in the Bay of Seine. J Mar Biol Assoc UK 74:129-142

Tuck GN, Possingham HP (2000) Marine protected areas for spatially structured exploited stocks. Mar Ecol Prog Ser 192:89-101

Vargas CA, Narváez DA, Piñones A, Venegas RM, Navarrete SA (2004) Internal tidal bore warm fronts and settlement of invertebrates in central Chile. Estuar Coast Shelf Sci 61: 603-612

Wahle RA, Incze LS (1997) Pre- and post-settlement processes in recruitment of the American lobster. J Exp Mar Biol Ecol 217:179-207

Wahle RA, Steneck RS (1991) Recruitment habitats and nursery grounds of the American lobster Homarus americanus: a demographic bottleneck? Mar Ecol Prog Ser 69:231-243

Wahle RA, Steneck RS (1992) Habitat restrictions in early benthic life: experiments on habitat selection and in situ predation with the American lobster. J Exp Mar Biol Ecol 157:91-114

Wing SR, Largier JL, Botsford LW, Quinn JF (1995) Settlement and transport of benthic invertebrates in an intermittent upwelling region. Limnol Oceanogr 40:316-329

Wing SR, Botsford LW, Largier JL, Ralston S (1998) Meroplanktonic distribution and circulation associated with a coastal retention zone in the northern California upwelling system. Limnol Oceanogr 43:1710-1721

Wolanski E, Hamner WM (1988) Topographically controlled fronts in the ocean and their biological influence. Science 241:177-181

Wood L, Hargis WJ (1971) Transport of bivalve larvae in a tidal estuary. In: Crisp DJ (ed) Proceedings of the 4th European marine biology symposium. Cambridge University Press, London, p 459-475

Submitted: April 1, 2005; Accepted: November 29, 2005 Proofs received from author(s): June 9, 2006 